\title{
CONTRACULTURA E TRANSGRESSÃO: uma análise do álbum "tropicalia ou panis et circencis" (1968)
}

\author{
Bruno Sanches Mariante da Silva* \\ Jessica Yohana Gonçalves**
}

RESUMO: O movimento tropicalista é um exemplo significativo das manifestações culturais que caracterizaram a década de 1960 no Brasil. A influência mútua aproximou músicos que sentiam-se desafiados à crítica cultural do período. O presente artigo intenta mostrar a Tropicália como um movimento de contracultura que se propôs a evidenciar certas práticas e costumes conservadores da sociedade brasileira, bem como a transgredi-los. A crítica proposta nas músicas vai além daquela endereçada às forças repressoras do Estado-militar, e abrangem as posturas conservadoras no âmbito musical, estético, comportamental e sexual. Lançado no ano de 1968 o disco-manifesto coletivo Tropicália ou panis et circencis, representa um novo momento na canção brasileira: a abertura explícita aos diálogos culturais. O estudo de algumas canções desse disco-manifesto é o que impulsiona esse estudo.

PALAVRAS-CHAVE: Tropicália; Contracultura; Música de resistência; Ditadura Militar.

\section{Counterculture and transgression: an analysis of the album "tropicalia ou panis et circencis" (1968)}

ABSTRACT: Tropicalismo movement is a significant example of the cultural manifestations that characterized the 1960s in Brazil. The mutual influence approached musicians who felt challenged by the cultural critique at that time. The present article tries to show "Tropicália" as a counterculture movement that aimed to highlight certain conservative practices and customs of Brazilian society, as well as to transgress them. The criticism proposed in the songs goes beyond that one addressed against the repressive forces that composed the military state, and it includes conservative positions in the musical, aesthetic, behavioral and sexual aspects. Released in 1968, the collective "manifest álbum" "Tropicália or panis et circencis" represents a new moment in Brazilian music: the explicit opening to cultural dialogues. The study of some of the songs from this manifest-album is the proposal of this present study.

KEYWORDS: Tropicália; Counterculture; Resistance music; Military dictatorship.

\section{Contracultura y transgresión: un análisis del álbum "tropicália o panis et circencis" (1968).}

RESUMEN: El movimiento tropicalista es un ejemplo significativo de las manifestaciones culturales que marcaron la década de 1960 en Brasil. La influencia mutua acercó músicos que se sentían desafiados por la crítica cultural del período. El presente artículo intenta mostrar la Tropicália como un movimiento de contracultura que se propuso a evidenciar ciertas prácticas y costumbres conservadores de la sociedad brasileña, así como a transgredirlos. La crítica propuesta en las canciones va más allá de la aquella dirigida a las fuerzas represoras del Estado-militar, y abarca las posturas conservadoras en el ámbito musical, estético, comportamental y sexual. Lanzado en el año de 1968, el disco-manifiesto colectivo "Tropicália ou Panis et circencis", representa un nuevo momento en la música brasileña: la apertura explícita a los diálogos culturales. El análisis de algunas canciones de ese disco-manifiesto es lo que impulsa ese artículo.

PALABRAS CLAVE: Tropicália; Contracultura; Música de resistencia; Dictadura militar.

\footnotetext{
*Mestre em História pela Universidade Estadual Paulista "Júlio de Mesquita Filho" (Unesp/Assis) e doutorando em História e Sociedade pela mesma universidade. Professor junto ao Departamento de História da Faculdade de Filosofia, Ciências e Letras de Mandaguari (FAFIMAN). Contato: Faculdade de Filosofia, Ciências e Letras de Mandaguari, Estrada para S. Pedro, s/n Km 1, 86975-000 Mandaguari-PR, Brasil. E-mail: bruno.silva@unifil.br.

** Graduada em História pela da Faculdade de Filosofia, Ciências e Letras de Mandaguari (FAFIMAN). E-mail: yohanagoncalves92@hotmail.com.
} 
É no contexto da implantação de um regime militar ditatorial no Brasil ${ }^{1}$ que surge, em 1968, um dos movimentos culturais mais diversificados da história artística brasileira. Chamado de Tropicália, o movimento tinha por objetivo dar origem a "algo diferente de tudo" (VELOSO, 2012, p. 112), rompendo com a música popular existente no país nesse período. Caracterizado como um movimento de "contracultura", conceito surgido na imprensa norte-americana nos anos 1960 para designar os movimentos alternativos de caráter eclético, místico-político. As manifestações da contracultura, em geral, objetivavam rebelar-se contra os valores instituídos pela sociedade norte-americana, engendrando uma cultura marginal que se pautou pela transcendência do mundo capitalista e tecnocrático (BARROS, 2007).

O movimento Tropicália ou Tropicalismo contava com Gilberto Gil e Caetano Veloso na liderança, e também com as participações de Tom Zé, Rogério Duprat, Os Mutantes (grupo formado por Arnaldo Baptista, Sérgio Dias e Rita Lee), e aparições casuais de Torquato Neto, Nara Leão e Rogerio Duarte. Todos esses artistas participaram do disco-manifesto Tropicália ou Panis et Circencis - lançado em 1968, e que constitui fonte e objeto do presente artigo.

O ano de 1968 foi marcado por fortes ebulições, transformando aspectos políticos e culturais, tanto no Brasil quanto mundo a fora. Na Europa, mais especialmente na França, é de grande relevância uma série de manifestações promovidas por jovens estudantes e intelectuais que ficou conhecido como "Maio de 1968". Essencialmente fomentado por movimentos de esquerda e anarquistas, os eventos na França obtiveram grande destaque na história francesa, consolidando uma série de transformações na estrutura da educação universitária. Os eventos do "Maio de 68" refletiram e fascinaram os universitários de São Paulo e Rio de Janeiro, que também se organizaram em tentativas de resistência e revolta estudantil.

Foi um ano marcado por vários acontecimentos como o desenvolvimento comercial da pílula anticoncepcional, que transformaria profundamente a vida sexual, especialmente das mulheres, desassociando o sexo definitivamente da reprodução humana; o assassinato do líder dos movimentos por direitos civis nos Estados Unidos, Martin Luther King Jr; de protestos veementes contra a guerra do Vietnã e em prol da paz; da propagação da cultura de livre experimentação de drogas; de certa intensificação dos movimentos feministas. Os jovens dos anos 1960 possuíam uma extensa e diversificada pauta de reivindicações visando transformações sociais bastante profundas. 
A cultura jovem tornou-se a matriz da revolução cultural no sentido mais amplo de uma revolução nos modos e costumes, nos meios de gozar o lazer e nas artes comerciais, que formavam cada vez mais a atmosfera respirada por homens e mulheres urbanos. Duas de suas características são portando relevantes. Foi ao mesmo tempo informal e antinômica, sobretudo em questões de conduta pessoal. Todo mundo tinha de "estar na sua", com o mínimo de restrição externa, embora na prática a pressão dos pares e a moda impusessem tanta uniformidade quanto antes, pelo menos dentro dos grupos de pares e subculturas (HOBSBAWM, 2012, p.323)

Conforme apontado por Hobsbawm (2012), a cultura jovem dominaria o período, especialmente as décadas de 1960 e 1970. É relevante também apontarmos a força que as subculturas passaram a ter, como veremos, mais especificamente, no caso da música brasileira e os embates acerca de sua diversidade. Desse modo, um grande fenômeno desse período é a consolidação de força social da juventude. Roszak (1972) apontara que entre 1945 e 1964 nasceram 86 milhões de bebês só nos Estados Unidos, fenômeno que ficou conhecido como baby boom ${ }^{2}$. Os jovens soldados que retornavam da guerra e as propagandas de um forte aquecimento econômico - os chamados anos dourados - motivaram as famílias a gerarem mais filhos. Esses jovens que se engajavam na luta contra o sistema e a elite burguesa eram, portanto, os filhos do período pós-guerra, chamados, assim, baby boomers. Jovens que, sem saber, cresceram para fazer parte da automação do sistema capitalista. Cada bebê é um consumidor em potencial, mesmo sem consciência disto, pois até que chegue em sua fase préadolescente ou adulta será sustentado por produtos consumidos pelos pais. Ao adentrar a fase adulta, além de consumir, se torna mão-de-obra para o mercado de trabalho, mantendo aquecida a economia. Sem contar a moda, que surgirá ainda mais imponente do que nos anos 1950, com os tênis e calças jeans num processo de uniformização da juventude. É contra esse processo que muitos grupos se levantarão (CORREIA, 1989).

A consciência dessa sua condição, aliada a certo ideário marxista ou anarquista, formou certos conflitos ideológicos geracionais. Para as gerações anteriores, os jovens de então eram mimados e inconsequentes. Para os baby boomers, o que eles queriam era mudar o mundo. Nesse período, contudo, a juventude brasileira também apresentava certa radicalização de novos procedimentos para o debate de suas rotas políticas e estéticas do Brasil. O comportamento já apontara a visão revolucionária, que tinha como referência Karl Marx, Che Guevara e Léon Trotsky. Podemos dizer também que a revolução que esse esperava, a partir dos jovens, provinha especialmente das classes médias e educadas, uma vez que essa geração adquiria a base do conhecimento por meio da literatura - especialmente estrangeira -, não se preocupavam tanto com a imagem e mais com a leitura, mesmo em um 
período de franco avanço da tecnologia da televisão. Voltavam então sua atenção para o teatro, o cinema e os festivais de canção que eram referência neste período.

Experimentava-se uma renovação no campo cultural. No Brasil, vivia-se a era dos festivais televisionados e da Bossa Nova, que dividia o espaço com outro movimento chamado "Jovem Guarda", formado por jovens inspirados por guitarras elétricas de Jimi Hendrix e Beatles (GARCIA, 2017). No entanto, os setores mais conservadores não aceitavam a convivência da Jovem Guarda e a MPB (Música Popular Brasileira), fechando então o círculo para aqueles que foram acusados de tentar acabar com a renovação da música brasileira, até então maciçamente influenciada pela Bossa Nova. Nesse contexto entre conservadores e progressistas musicais, em 1967, foi organizada uma estranha passeata contra as guitarras em defesa das "raízes da música popular brasileira".

\begin{abstract}
Havia uma rivalidade muito estimulada pela TV Record também, que tinha um monopólio dos musicais da época, televisão não tinha novela, o forte da televisão era a música e a Record tinha sob contrato $90 \%$ da música brasileira. Todo dia tinha um programa musical e a Record tinha interesse que os programas de televisão fossem para os jornais, para as rádios, para a vida das pessoas, então era engraçado porque na época se dizia que a MPB era a música brasileira e Jovem Guarda era a música jovem. E a gente pensava: Meu Deus do céu, por que não pode haver uma música jovem e brasileira ao mesmo tempo? Uma pergunta óbvia, mas que era pertinente nesse tempo a ponto de as pessoas organizarem uma passeata em plena ditadura militar, com tanta coisa para protestar! Organizar uma passeata com 300, 400 pessoas, com faixa, cartaz e as pessoas gritando: "Abaixo à guitarra! Abaixo à guitarra!" A guitarra elétrica como símbolo do imperialismo ianque, aqueles clichês do velho comunismo que estavam muito ativos na época. (Depoimento de Nelson Motta em Uma noite em 67 (Renato Terra, Ricardo Calil, 2010)
\end{abstract}

Nesse meio tempo, alguns jovens baianos acreditavam que a música poderia ser melhor, ou pelo menos muito diferente, do que aquilo que já estava sendo feito, sem desprezar o que já existia. Entre eles estavam Gilberto Gil, Caetano Veloso e mais alguns amigos também baianos. Todos muito motivados pelo som de João Gilberto, iniciariam efetivamente a partir dali suas carreiras na música. Apesar de terem sucesso nos festivais e em alguns programas de TV, fazendo arte dentro daquilo que era chamado de nova música brasileira, Gil e Caetano não estavam satisfeitos. A primeira vez que Caetano ouviu os Beatles, através de Gil, percebeu que havia ali algo que poderia ser feito além daquilo que se chamava de música popular brasileira.

A lição que, desde o início, Gil quisera aprender dos Beatles era a de transformar alquimicamente lixo comercial em criação inspirada e livre, reforçando assim a autonomia dos criadores - e dos consumidores. (VELOSO, 2012, p.164) 
A Tropicália surgiu, então, como um movimento em uma época bastante agitada, trazendo como objetivos ampliar os horizontes, fossem esses políticos, comportamentais, sociais, sexuais ou artísticos. Partindo de uma juventude que nasceu durante ou logo após a Segunda Guerra Mundial e se opunha a falta de liberdade, especialmente infligida no Brasil com o golpe militar de 1964 e o recrudescimento da ditadura em 1968 (FICO, 2015).

Durante a ditadura militar, foram editados vários atos institucionais, porém o de maior impacto efetivo nas vidas cotidianas foi o Ato Institucional $\mathrm{n}^{\circ} 5$, conhecido como AI-5. Editado em 13 de dezembro de 1968, o AI-5 suspendia o "habeas corpus" e deixava clara a premissa de torturar e implicar a violência nos opositores ao regime militar. Segundo Zuenir Ventura, jornalista que adquiriu proeminência por narrar fatos do período, em seu livro sobre o ano de 1968 destacou que:

\begin{abstract}
Quando os militares deram o golpe em abril de 64, abortaram uma geração cheia de promessas e esperanças. A esquerda, como acreditava Luis Carlos Prestes então, não estava no governo, mas já estava no poder. As reformas de base de João Goulart iriam expulsar o subdesenvolvimento e a cultura popular iria conscientizar o povo [...] onipotente, generosa, megalômana, a cultura pré-64 alimentou a ilusão de que tudo dependia mais ou menos de sua ação: ela não só conscientizaria o povo como transformaria a sociedade, ajudando a acabar com as injustiças sociais. Essa ilusão acabou em 64; a inocência em 68. (VENTURA, 2008, p. 44)
\end{abstract}

Os militares tentavam refrear ideias e ações dos militantes de esquerda, em geral oriundos de movimentos sociais da época, especialmente os estudantis.

A Tropicália alavancou-se com uma proposta político-social diferenciada, uma vez que não apoiava os militares e muito menos se denominava de esquerda, confundindo assim o público receptor que estava no meio do confronto político entre os militares e os "comunistas". Mais adiante, Caetano Veloso, um dos líderes do tropicalismo, foi vaiado enquanto cantava a canção "É proibido proibir" (frase anarquista recorrentemente pichada em vários protestos na França durante as manifestações de maio de 1968). Ao final da canção, Caetano esbravejou: "Vocês não estão entendendo nada! Nada!". A proposta tropicalista era realmente de difícil compreensão, pois valia-se de canções, roupas e expressões com as quais o grande público ainda estava pouco familiarizado, causando-lhe estranheza. Muitas vezes a percepção do público receptor é que o grupo tropicalista falava uma coisa, mas deseja dizer outra, o que os confundia demasiadamente. Anos mais tarde, o cantor e compositor Tom Zé cantou que "eu tô te explicando pra te confundir, eu tô te confundindo pra te esclarecer", reforçando a perspectiva de uma dialética bastante irônica no tropicalismo. 


\section{Desenvolvimento da identidade tropicalista}

Os Tropicalistas procuravam uma forma de fazer música que fosse a mais brasileira possível, para tal assimilaram diversas influências, como o programa do Chacrinha ${ }^{4}$, a quem consideravam uma mistura tipicamente nacional. Nas artes plásticas, artistas como Andy Warhol e Hélio Oiticica formaram importantes referências estéticas para os integrantes do movimento.

Caetano Veloso, Maria Bethânia, sua irmã mais nova, e seu grupo de amigos de Santo Amaro da Purificação, pequena cidade do recôncavo baiano, cresceram em contato com os sambas baianos, bem como com a música europeia, diferente dos jovens daquela época. Naquele momento, o rock americano também não os agradou, foi somente, quando todos já moravam no Rio de Janeiro, e quando Gilberto Gil retornou de uma viagem a Pernambuco, que suas atenções começaram a convergir para o rock britânico:

Por isso é que os Beatles nos interessavam como o rock'n'roll dos anos 50 não tinha podido fazer. O mais importante não seria tentar reproduzir os procedimentos musicais do grupo inglês, mas a atitude em relação ao próprio sentido da música popular como um fenômeno. Sendo que, no Brasil, isso deveria valer por uma fortificação da nossa capacidade de sobrevivência histórica e de resistência à opressão. (VELOSO, 2012, p.164)

Outras influências explicadas pelo próprio Caetano Veloso, em seu livro de memória musical "Verdade Tropical”(2012), foi o filme "Terra em Transe", do diretor - também baiano - Glauber Rocha. A obra do cineasta foi uma referência fundamental para a escolha estética do movimento tropicalista. Caetano relata que já morava no Rio de Janeiro, quando assistiu ao filme, lançado em maio de 1967, e considerado a principal obra do Cinema Novo, movimento estético e cinematográfico que se caracterizou por imagens que chocavam o público, uma vez que eram feitas com poucos recursos e julgadas, portanto, como "feias". Para Veloso, era isso que faria o movimento render e que também mostraria como o Brasil era visto pelo mundo, isto é, feio e precário.

Nesse período, a TV Record, emissora referência nacional na época no quesito música, exibia alguns programas importantes como "O fino da bossa” apresentado por Elis Regina, a grande cantora brasileira do momento, e Jair Rodrigues, representantes da MPB e do samba; e também o programa Jovem Guarda, apresentado por Roberto Carlos, um dos protagonistas do rock brasileiro. Além disso, a emissora promovia festivais de música que atraiam o público jovem e universitário e diversos outros telespectadores. 
Foi no III Festival de Música Popular Brasileira da Record, em 1967, que o movimento tropicalista se lançou publicamente. Caetano Veloso acompanhado do grupo "Beat Boys" e vestido com terno xadrez, cantou "Alegria, alegria", que ficou conhecida como uma música-hino da Tropicália. Junto de Gilberto Gil, Caetano decidiu que o festival iria ser a deflagração da revolução musical que pretendiam. Queria compor uma canção que fosse fácil de aprender por parte dos espectadores do festival, mas ao mesmo tempo caracterizasse a nova atitude que queriam inaugurar (VELOSO, 2012, p.166). Nesse mesmo festival, Gil cantou "Domingo no parque" acompanhado do grupo de rock "Os Mutantes". De certa forma as duas músicas foram bem recebidas pelo público, dando oportunidade para que o movimento começasse a se destacar. Logo após o festival de 1967, Caetano compôs a música “Tropicália”, cujo nome fora sugestão do fotógrafo Luís Carlos Barreto, em referência à obra de Hélio Oiticica (1937-1980). Oiticica havia elaborado uma instalação constituída por um labirinto de madeira forrado com areia e pedras, que, ao ser percorrido pelo espectador, colocava-o em contato sensorial com diversos elementos naturais e culturais do Brasil, como plantas tropicais e araras nativas, num percurso que terminava em frente a um aparelho de televisão ligado. O título da instalação de Oiticica foi importado, então, pelo movimento, que logo ganhou forma e êxito.

Favaretto afirma, que o "tropicalismo surgiu mais de uma preocupação entusiasmada pela discussão do novo, do que propriamente como movimento organizado" (1996, p. 17). Em uma declaração a Favareto, Caetano Veloso afirmou que:

Eu e Gil estávamos fervilhando de novas idéias. Havíamos passado bom tempo tentando aprender a gramática da nova linguagem que usaríamos, e queríamos testar nossas idéias, junto ao público[...] Trabalhando noite adentro, juntamente com Torquato Neto, Gal, Rogério Duprat e outros. Ao mesmo tempo, mantínhamos contatos com artistas de outros campos, como Glauber Rocha, José Celso Martinez, Hélio Oiticica e Rubens Gerchman. Dessa mistura toda nasceu o tropicalismo e a tentativa de superar nosso desenvolvimento partindo exatamente do elemento "cafona" da nossa cultura, fundindo ao que houvesse de mais avançado industrialmente, como guitarras e as roupas de plástico. Não posso negar o que já li, nem posso esquecer onde vivo (FAVARETTO, 1996, p.24).

A imprensa passou a se referir aos seus integrantes como "tropicalistas" e promovia comparações entre as correntes de pensamentos, opondo o movimento a outros movimentos estudantis de resistência que tinham como referência, principalmente, Chico Buarque e Geraldo Vandré. Os periódicos da época vendiam notícias e estimulavam o interesse do público pelo tema, mesmo que fosse um público alinhado a um pensamento de esquerda, e bastante interessado na luta armada. 


\section{"Tropicalia ou panis et circencis": o disco de manifesto do movimento}

Em agosto de 1968, tropicalistas se reuniram para o lançamento do que seria o ápice musical do movimento, o long-play manifesto "Tropicália ou Panis et Circencis" pela gravadora Phillips. O álbum contou com a participação de Tom Zé, Os Mutantes, Gal Costa, Nara Leão, além de Caetano e Gil, os líderes do movimento. O disco também contou com a colaboração de Rogério Duprat para os arranjos.

No ano de 2007 a revista Rolling Stone Brasil promoveu uma eleição dos 100 maiores discos brasileiros de todos os tempos, "Tropicália ou panis et circencis" alcançou o segundo lugar, demostrando certa vitalidade e importância histórico-musical do álbum. É preciso de antemão ressaltar que o disco-manifesto não foi o primeiro disco dos tropicalistas, pois os discos individuais de Caetano e Gil de 1968, foram gravados antes do disco coletivo, mas lançados posteriormente.

A Tropicália se assumia como um "antimovimento" ou algo parecido como o "movimento para acabar com os outros movimentos". O fato é que o álbum de 1968 constituiu o manifesto do grupo e é também sua própria arte. "Tropicalia ou panis et circencis" é o trabalho mais lembrado e significativo do tropicalismo, pois reuniu compositores, arranjadores, interpretes produtores e compositores tropicalistas.

Figura 1: Reprodução da capa do Álbum "Tropicalia ou panis et circencis" (1968).

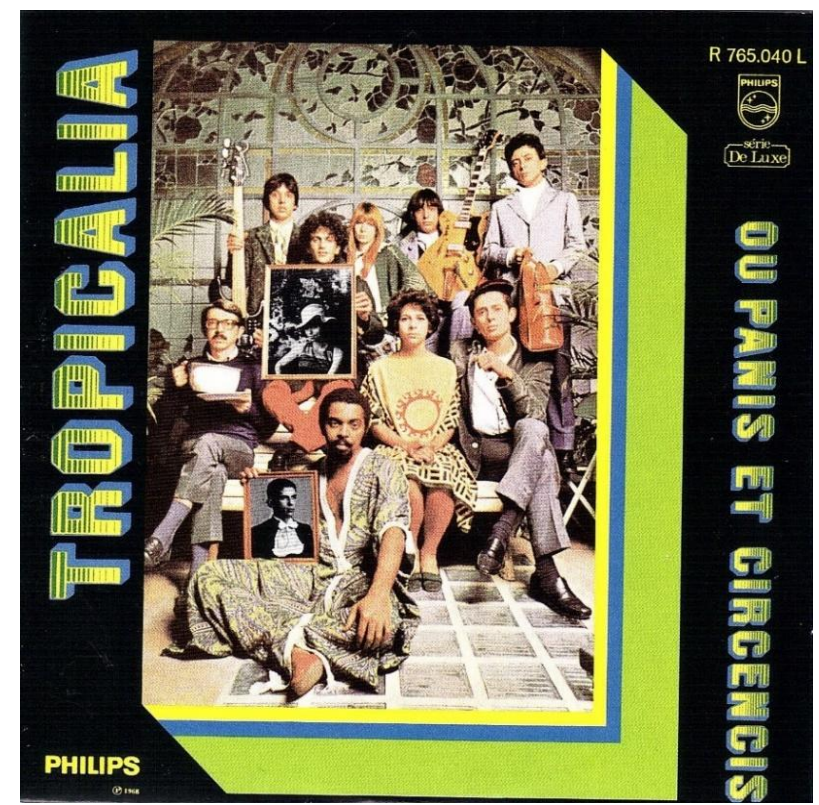

Fonte: Acervo pessoal. 
Mais uma vez, cabe ressaltar que o movimento tropicalista pretendia ir além da estética e composição musical e unia-se às artes plásticas. Dessa maneira, na estética da capa do álbum-manifesto podemos observar muitos dos procedimentos que estão presentes na concepção e execução do disco que, nas palavras de Celso Favaretto (1996, p. 78), é a "suma tropicalista”. O autor ainda observou que o disco apresenta os elementos que compunham significativamente a estética tropicalista, isto é, "carnavalização, festa, alegoria do Brasil, crítica da musicalidade brasileira, crítica social, cafonice" e a própria capa já "compõe a alegoria do Brasil que as músicas apresentarão fragmentariamente" (FAVARETTO, 1996, p. 78-79).

A fotografia que estampou a capa do álbum foi realizada em São Paulo na casa de Oliver Perroy, fotógrafo da Editora Abril. Cada um dos membros do grupo apanhou alguns apetrechos para lhes acompanhar na fotografia, desde penico até instrumentos musicais, como por exemplo a guitarra elétrica. A fotografia ficou tão famosa que virou símbolo do movimento tropicalista, uma espécie de cartão postal. A ideia era de fazer uma paródia das fotos de família que, tradicionalmente, as classes abastadas brasileiras costumavam fazer, e ao mesmo tempo também remeter a capa do disco clássico dos Beatles "Sgt. Pepper's Lonely Hearts Club Band”, lançado em maio de 1967. Estão ausentes, fisicamente, na foto Capinam e Nara Leão, que depois foram inseridos nas molduras vazias que Gil e Caetano seguravam.

A produção do disco foi coletiva. As canções possuem um caráter estético, subliminar, subversivo e trazendo consigo frequentemente um caráter mais implícito do que explícito. As faixas misturavam rock, pop, samba, bossa nova, mambo, baião e bolero. A intenção era desconstruir tudo, desorganizar para então organizar o seu próprio movimento. Esse caos e confusão vinham da concepção dos artistas que alguma coisa estava fora de ordem na música e na sociedade brasileiras. $\mathrm{O}$ disco foi gravado sem intervalo entre as 12 faixas que compõem o álbum.

Em 1968, Gil e Caetano receberam um convite para apresentarem-se no Festival Internacional da Canção, uma versão da TV Globo para os festivais que estiveram em alta na TV Record. O festival na TV Globo trazia certas diferenças como os critérios de avaliação e também pela capacidade de público do local, agora realizado no estádio do Maracanãzinho, no Rio de Janeiro. Aceitaram, pois, o evento contava com grande visibilidade nesse período, e eles estavam dispostos a fazer daquele fato algo que marcasse significativamente o movimento. Inscreveram as canções "É proibido proibir", que Caetano apresentaria com Os Mutantes, e "Questão de Ordem" que Gil tocaria com os Beat Boys. 
Caetano, vestido com uma roupa verde e preta de plástico, com colares de fios com tomadas nas pontas - mais uma vez provocando certa ruptura com dogmas da moda do período -, foi bastante vaiado por boa parte do público, porém foi classificado para a semifinal. No entanto, Gil e os Beat Boys logo no primeiro minuto de apresentação foram vaiados e recebidos com ovos pelo público, e a música foi desclassificada pelo júri. Caetano em sua próxima apresentação, voltou ao palco e proferiu um discurso improvisado que marcou aquele evento, acusando a plateia de ignorantes. Segue transcrita parte de sua fala:

Mas isso que é a juventude que diz que quer tomar o poder? Vocês têm coragem de aplaudir, este ano, uma música, um tipo de música que vocês não teriam coragem de aplaudir no ano passado? São a mesma juventude que vão sempre, sempre, matar amanhã o velhote inimigo que morreu ontem! Vocês não estão entendendo nada, nada, nada, absolutamente nada. (Documentário Tropicália, 2012)

Os tropicalistas desagradavam boa parte dos intelectuais, dos músicos e principalmente a imprensa. O rock'n roll norte americano, as guitarras elétricas e a estética tropicalista geraram uma rejeição por parte de muitos. Chegaram à conclusão de que a Música Popular Brasileira estava se "americanizando", era, então, necessário encontrar aqueles que estivessem perdidos entre a esquerda e a direita durante a ditadura militar, parar receber e entender então o que era Tropicália.

O motivo pelo qual o uso de guitarras elétricas em um festival de música popular havia se tornado um ponto tão delicado e contencioso se devia à posição que esta ocupava no Brasil do fim dos anos 60. No período que começa com o início da ditadura militar em 1964 - e que em certa medida se encerraria em 1968, ao ser decretado o AI-5 -, a música popular havia se tornado o veículo privilegiado de dissensão política. No imaginário cultural da época, correspondia à música popular, em grande parte, o papel de articular um ideal de nação - concebido em função de revalorizar suas "raízes" culturais - e de exercer a liberdade de expressão em clara oposição ao projeto ideológico e político dos militares. (BASUALDO, 2007, p.12)

O tropicalismo não criticava necessária e diretamente a ditadura, mas adereçava suas críticas mais contundentes às censuras morais impostas pelo regime. Criticavam, especialmente, a base moral reacionária, isto é, os elementos que suportavam a moral e os julgamentos dela correntes. Esses elementos eram: Família, Igreja e Estado. O conjunto de críticas construído pelos tropicalistas pode ser percebido pelas canções que compõem o álbum-manifesto de 1968. 


\section{Canções do álbum}

O álbum "Tropicalia ou panis et circencis" apresenta 12 canções, dividas em lado A e lado B. A maioria das músicas fora composta pelos próprios membros do grupo-movimento, com exceção de "Coração Materno", de autoria de Vicente Celestino; Três Caravelas, uma versão de João de Barro para uma canção em espanhol; e Hino ao Senhor do Bonfim de autoria de Artur de Sales e João Antônio Wanderley. Assim, as faixas que compõem o álbum são:

Tabela 1: Tabela com as doze canção que compõe o disco "Tropicalia ou panis et circencis" de 1968.

\begin{tabular}{|c|c|c|c|}
\hline Faixa & Título & Compositores & Intérpretes \\
\hline \multicolumn{4}{|l|}{ Lado A } \\
\hline 1. & "Miserere Nóbis" & $\begin{array}{l}\text { Capinam, Gilberto } \\
\text { Gil }\end{array}$ & Gilberto Gil \\
\hline 2. & "Coração Materno" & Vicente Celestino & Caetano Veloso \\
\hline 3. & "Panis et Circencis" & $\begin{array}{l}\text { Caetano Veloso, } \\
\text { Gilberto Gil }\end{array}$ & Os Mutantes \\
\hline 4. & "Lindoneia" & Caetano Veloso & Nara Leão \\
\hline 5. & "Parque Industrial" & Tom Zé & $\begin{array}{l}\text { Gilberto } \text { Gil, } \\
\text { Caetano Veloso, } \\
\text { Gal Costa, Os } \\
\text { Mutantes e Tom } \\
\text { Zé }\end{array}$ \\
\hline 6. & "Geléia Geral" & $\begin{array}{l}\text { Gilberto Gil, } \\
\text { Torquato Neto }\end{array}$ & Gilberto Gil \\
\hline \multicolumn{4}{|l|}{ Lado B } \\
\hline 1. & "Baby" & Caetano Veloso & $\begin{array}{l}\text { Gal Costa e } \\
\text { Caetano Veloso }\end{array}$ \\
\hline 2. & $\begin{array}{l}\text { "Três Caravelas (Las Tres } \\
\text { Carabelas)" }\end{array}$ & $\begin{array}{l}\text { Algueró } \quad \text { Jr., } \\
\text { Moreau. Versão: } \\
\text { João de Barro }\end{array}$ & $\begin{array}{l}\text { Caetano Veloso e } \\
\text { Gilberto Gil }\end{array}$ \\
\hline 3. & $\begin{array}{l}\text { "Enquanto seu Lobo Não } \\
\text { Vem" }\end{array}$ & Caetano Veloso & $\begin{array}{ll}\text { Caetano } & \text { Veloso, } \\
\text { Gilberto } & \text { Gil e } \\
\text { Rita Lee } & \end{array}$ \\
\hline 4. & "Mamãe, Coragem" & $\begin{array}{l}\text { Caetano Veloso, } \\
\text { Torquato Neto }\end{array}$ & Gal Costa \\
\hline 6. & "Hino ao Senhor do Bonfim" & $\begin{array}{l}\text { Artur de } \begin{array}{r}\text { Sales, } \\
\text { João Antônio } \\
\text { Wanderley }\end{array}\end{array}$ & $\begin{array}{l}\text { Caetano Veloso, } \\
\text { Gal Costa, } \\
\text { Gilberto Gil e Os } \\
\text { Mutantes }\end{array}$ \\
\hline
\end{tabular}

Em sua maioria, as canções criticavam a forma estética de se fazer canções. As canções possuem uma sonoridade "desordenada e caótica", como uma maneira de romper com a estética harmônica da música até então produzida. Não só as melodias e arranjos eram vistos com desconfiança, mas, sobretudo, as letras das canções, pois eram carregadas de mensagens subliminares, o que acarretava que fossem ouvidas com relativa suspeição. As canções eram (são), portanto, de difícil compreensão. Algumas faixas de destaque do álbum 
serão aqui analisadas. A primeira delas é "Miserere Nobis", composta por Gilberto Gil e Capinam, e interpretada pelo primeiro. A faixa abre o álbum manifesto e sua temática promove certa aproximação entre a religião e o governo militar.

\author{
Ora, ora pro nobis \\ É no sempre será, ô, iaiá \\ É no sempre, sempre serão \\ Já não somos como na chegada \\ Calados e magros, esperando o jantar \\ $\mathrm{Na}$ borda do prato se limita a janta \\ As espinhas do peixe de volta para o \\ mar \\ Miserere-re nobis \\ Ora, ora pro nobis \\ É no sempre será, ô, iaiá \\ É no sempre, sempre serão \\ Tomara que um dia de um dia seja \\ Para todos e sempre a mesma cerveja \\ Tomara que um dia de um dia não \\ Para todos e sempre metade do pão \\ Tomara que um dia de um dia seja \\ Que seja de linho a toalha da mesa \\ Tomara que um dia de um dia não \\ Na mesa da gente tem banana e feijão \\ Miserere-re nobis
}

\author{
Ora, ora pro nobis \\ É no sempre será, ô, iaiá \\ É no sempre, sempre serão \\ Já não somos como na chegada \\ O sol já é claro nas águas quietas do \\ mangue \\ Derramemos vinho no linho da mesa
}

Molhada de vinho e manchada de sangue

Miserere-re nobis

Ora, ora pro nobis

É no sempre será, ô, iaiá

É no sempre, sempre serão

Bê, rê, a - Bra

Zê, i, lê - zil

Fê, u - fu

Zê, i, lê - zil

Cê, a - ca

Nê, agá, a, o, til - nhão

Ora pro nobis

A música que inicia com o som de um órgão em clima de música sacra termina com tiros de canhão. O título da canção em latim significa "Tende piedade de nós", e a primeira frase da canção, também em latim, é a mesma que encerra a canção, "Ora pro nobis”, cujo significado é "orai por nós”. Todos esses primeiros elementos apontados corroboram a formação de um cenário religioso na canção. Os compositores parecem escolher a religião, especialmente a católica, para ser a temática da canção. No entanto, nos últimos seis versos da canção as sílabas que são soletradas formam as palavras "Brazil", "fuzil" e "canhão", aproximando da temática militar. Fica evidente uma aproximação entre as duas instituições, a Igreja e o Exército.

A música tem um forte viés contestatório da situação da população brasileira, mormente querendo representar a desigualdade social: "Tomara que um dia de um dia seja/ Para todos e sempre a mesma cerveja/ Tomara que um dia de um dia não / Para todos e sempre metade do pão / Tomara que um dia de um dia seja / Que seja de linho a toalha da mesa / Tomara que um dia de um dia não / Na mesa da gente tem banana e feijão.” Para logo em seguida fazer referência a uma luta: "Derramemos vinho no linho da mesa / Molhada de vinho e manchada de sangue". Como já havíamos destacado tanto o Exército quanto a Igreja, 
enquanto instituições, estavam no foco da contestação dos tropicalistas, uma vez que representavam fortemente os setores conservadores da sociedade. Esses aspectos também aparecem na faixa título do álbum. Panis et circencis, foi composta pela dupla Caetano e Gil e interpretada pelo grupo "Os Mutantes" e tornou-se a música mais conhecido do álbum.

Eu quis cantar
Minha canção iluminada de sol
Soltei os panos sobre os mastros no ar
Soltei os tigres e os leões nos quintais
Mas as pessoas na sala de jantar
São ocupadas em nascer e morrer
Mandei plantar
Folhas de sonho no jardim do solar
As folhas sabem procurar pelo sol
E as raízes procurar, procurar
Mas as pessoas na sala de jantar

\author{
Mandei fazer \\ De puro aço luminoso um punhal \\ Para matar o meu amor e matei \\ Às cinco horas na avenida central \\ Mas as pessoas na sala de jantar \\ São ocupadas em nascer e morrer \\ Essas pessoas na sala de jantar \\ São as pessoas da sala de jantar \\ Mas as pessoas na sala de jantar \\ São ocupadas em nascer e morrer
}

Panis et circenses é a terceira faixa do disco, e marca de forma indelével uma crítica a organização familiar daquele momento, representando também, de forma clara, a família como uma ditadura que oprime, enclausura e sufoca. É possível perceber oposições como liberdade x repressão, mas, para além disso, é possível depreendermos da canção uma representação de acomodação da família burguesa, pois enquanto nas ruas há confrontos com as forças policias representativas da ditadura militar em vigência, a música refere-se as pessoas da família em casa apenas preocupadas em jantar na sala-de-jantar. Os versos "Mas as pessoas na sala de jantar/ São ocupadas em nascer e morrer" são repetidos três vezes no final, denotando certa ênfase na mensagem do tipo de preocupação e da acomodação da família burguesa.

A canção tem como "pano de fundo" a realização de um jantar, não só na letra, mas também em sua sonoridade. Ouve-se o barulho de pessoas sentadas na mesa durante uma refeição, com os ruídos dos talheres, bem como de falas como, por exemplo, "me passa a salada, por favor”, “o pão, por favor”. Ao fundo, pode-se também ouvir a tradicional valsa "Danúbio Azul” de Johann Strauss II, mais uma vez fazendo menção a família burguesa seus gostos e costumes. O título da canção vem da expressão latina "Panis et circencis", cujo significado, "Pães e circo", faz referência ao costume do Império Romano de entreter o público com circo e alimentos. Dessa maneira, a canção representa um jantar em uma família burguesa, aliando não apenas a alimentação, com também a sociabilidade e o entretenimento que esse evento representa na sociedade. A canção procura, claramente, questionar e satirizar 
a comodidade e o conservadorismo desse modo de viver familiar, bem como enfatizar a alienação burguesa.

Em um programa da TV Cultura de São Paulo, Paulo Gaudêncio deu a seguinte declaração antes da execução da canção pelo Os Mutantes:

\begin{abstract}
O jovem quer ser adulto, o que o jovem não quer é ser como o adulto que ele tem diante dele: um adulto quadrado, chato, que não sabe viver, moralista, um adulto realmente nada atraente. (...) Existe um tipo de adulto que é detestável para um jovem que seja razoavelmente saudável. Será que os jovens já disseram isto alguma vez na música? Eles já disseram centenas de vezes na música. Existe uma delas que eu gostaria de pedir aos Mutantes que a executassem, e eu gostaria de pedir aos adultos que ouvissem: Panis et circensis. (GAUDÊNCIO in TROPICÁLIA, 2012)
\end{abstract}

Mais uma vez é invocada a figura do jovem, aquele jovem do Maio de 1968, o jovem das guitarras elétricas e o jovem das manifestações e protestos. A insatisfação geracional é um elemento bastante presente não só nesta canção, mas no movimento tropicalista como um todo.

A violência brutal, especialmente, impetrada pelas forças repressoras do aparelho estatal-militar aparece mais evidentemente na quarta canção do álbum, "Lindonéia", composição de Caetano Veloso e interpretação de Nara Leão.

Na frente do espelho

Sem que ninguém a visse

Miss

Linda, feia

Lindonéia desaparecida

Despedaçados

Atropelados

Cachorros mortos nas ruas

Policiais vigiando

O sol batendo nas frutas

Sangrando

Oh, meu amor

A solidão vai me matar de dor

Lindonéia, cor parda

Fruta na feira

Lindonéia solteira

Lindonéia, domingo

Segunda-feira

Lindonéia desaparecida

$\mathrm{Na}$ igreja, no andor
Lindonéia desaparecida

$\mathrm{Na}$ preguiça, no progresso

Lindonéia desaparecida

Nas paradas de sucesso

Ah, meu amor

A solidão vai me matar de dor

No avesso do espelho

Mas desaparecida

Ela aparece na fotografia

Do outro lado da vida

Despedaçados, atropelados

Cachorros mortos nas ruas

Policiais vigiando

O sol batendo nas frutas

Sangrando

Oh, meu amor

A solidão vai me matar de dor

Vai me matar

Vai me matar de dor

A canção Lindonéia foi inspirada no quadro "A Bela Lindonéia, ou A Gioconda do Subúrbio" (1966), obra Rubens Geshman, artista plástico bastante próximo ao grupo dos 
tropicalistas $^{6}$. A letra sugere que Lindonéia foi vítima de violência, mais do que isso sugere seu o desaparecimento. A conexão com a repreensão exercida pelo poder militar está também presente (a canção faz menção a "Policiais vigiando"). É possível, então, operarmos uma conexão com as práticas de repressão e violência policial as quais o povo brasileiro era submetido, na letra canção há maior ênfase às periferias das cidades. Especialmente a população negra, uma vez que tanto no quadro de Geshman quanto na canção de Caetano, Lindonéia é caracterizada como "parda", expressão comum para designar a pessoa negra de pele mais clara. Geshman chamou Lindonéia de "A Gioconda do subúrbio", uma menção a obra de Leonardo da Vinci "La Gioconda" (1503), também conhecida como "Mona Lisa".

A primeira canção do Lado B do álbum distancia-se um pouco da crítica e reflexão social, e vai pensar as questões próprias ao campo da música, principalmente, a música popular e suas relações com o capitalismo e as posturas consumistas. Trata-se de "Baby", de autoria de Caetano Veloso e interpretada por ele e Gal Costa. A canção ainda faria muito sucesso em uma interpretação d'Os Mutantes.

Você precisa
Saber da piscina
Da margarina
Da Carolina
Da gasolina
Você precisa
Saber de mim
Baby, baby
Eu sei
Que é assim
Baby, baby
Eu sei
Que é assim
Você precisa
Tomar um sorvete
Na lanchonete
Andar com gente
Me ver de perto
Ouvir aquela canção
Do Roberto
Baby, baby
Há quanto tempo
Baby, baby
Há quanto tempo

Você precisa Aprender inglês Precisa aprender O que eu sei E o que eu Não sei mais E o que eu Não sei mais

Não sei Comigo Vai tudo azul Contigo Vai tudo em paz Vivemos Na melhor cidade Da América do Sul Você precisa...

Não sei

Leia

Na minha camisa

Baby, baby I love you...

A canção de Caetano expõe, essencialmente, a relação da música com a cultura de massa, que é mais um dos elementos componentes do repertório crítico do tropicalismo. 
Nesse sentido, o grupo tropicalista procurava harmonizar as culturas ditas "erudita" e "popular". Dessa maneira, aparecem diversos elementos de uma cultura massificada, sobretudo, pelo consumismo. Ao longo da canção são recorrentes diversos itens que "você precisa", isto é, objetos ou práticas sociais sem as quais a vida moderna não está completa. Uma vez que se intenta em participar da cultura de massa da sociedade moderna, é preciso compartilhar desses elementos. Há, inclusive, referências aos músicos da moda, Chico Buarque (no verso "Da Carolina") e Roberto Carlos (e no verso "Ouvir aquela canção do Roberto"), como elementos que "você precisa", isto é, que o ouvinte precisa valer-se para fazer parte do mundo - da cultura de massa.

O estrangeirismo oriundo, sobretudo, do rock'n roll, com grande influência de bandas como Beatles e Rolling Stones, também está presente no próprio título da canção e sobre a necessidade de "falar inglês", um dos símbolos mais frequentes da cultura burguesa brasileira. O importante a ser destacado que Caetano faz esses apontamentos na canção, mas não apresenta uma crítica contundente a tais práticas. Há um certo desejo na alienação, como um escapismo a toda a opressão. "Baby" aparece ao mesmo tempo como uma rejeição e uma aceitação a esses valores massificados. A dialética presente na canção é a constatação da cultura pop como certa ilusão, uma fuga da realidade sob o julgo das ditaduras (comportamentais, sexuais e políticas); todavia é também a aceitação dessa cultura massificada como uma expressão artística genuína do momento histórico vívido.

A cultura pop também se faz presente na $11^{\mathrm{a}}$ faixa do álbum, Bat Macumba, composição da dupla Caetano e Gil e interpretada por Caetano Veloso, Gal Costa, Gilberto Gil e Os Mutantes.

Bat Macumba ê ê, Bat Macumba obá

Bat Macumba ê ê, Bat Macumba oh

Bat Macumba ê ê, Bat Macumba

Bat Macumba ê ê, Bat Macum

Bat Macumba ê ê, Batman

Bat Macumba ê ê, Bat

Bat Macumba ê ê, Ba

Bat Macumba ê ê

Bat Macumba ê

Bat Macumba

Bat Macum

Batman

Bat

$\mathrm{Ba}$

Bat

Bat Ma

Bat Macum 
Bat Macumba

Bat Macumba ê

Bat Macumba ê ê

Bat Macumba ê ê, Ba

Bat Macumba ê ê, Bat

Bat Macumba ê ê, Batman

Bat Macumba ê ê, Bat Macum

Bat Macumba ê ê, Bat Macumba

Bat Macumba ê ê, Bat Macumba oh

Bat Macumba ê ê, Bat Macumba obá!

Bat Macumba é um poema concreto, onde, com o andamento da canção, cada frase vai perdendo uma sílaba, até chegar ao mínimo de sílaba ("Ba"), para em seguida voltar a ser construída pelas sílabas originais, em uma forma totalmente simétrica. A canção traz em seu escopo elementos da cultura pop, como o personagem "Batman", e relaciona-o com um elemento característico da diversidade cultural e religiosa brasileira, especialmente as religiosidades de matriz africana. No Brasil, "macumba" é uma designação genérica para os culto afro-brasileiros. Além do jogo das sílabas que (de)formam as palavras "batman" e "macumba", é possível construirmos outras ligações não só com as palavras escritas, mas com a sonoridade que produzem. A palavra "bat" pode ser entendida como uma corruptela de "bate", que nos transporta para a percussão na música, mas também é possível relacionar com a palavra "macumba", uma vez que o vocábulo também designa um instrumento de percussão. Sobre as características tropicalistas impressas na canção, Matte considerou:

\footnotetext{
A letra da canção parte da macumba pop-iêiêiê para pelo menos duas citações, uma de antropofagia internacional ("batma", pronúncia freqüente para o nome do homem-morcego) e uma nacional (mas "ba", tchê!), bem ao estilo tropicalista. Assim, podemos ver que não há simultaneidade na construção dos sentidos na letra e na música, mas que o sentido global é feito por essas duas construções coordenadas, pois somente a análise consegue separar o sentido em dois. Nenhum deles sobrevive solitário, ao menos não com a mesma força. (MATTE, 2005, p.495)
}

A canção é uma analogia entre música-tema do seriado de TV e a um refrão de algum culto religioso. É uma espécie de modernidade "abrasileirada", onde mistura-se uma percussão afro-brasileira e uma viola fazendo soar como um solo de guitarra, com gritos e um coro, em um clima de terreiro de candomblé. Essa modernidade abrasileirada, ou essa mescla entre cultura pop internacional e elementos afro-brasileiros tradicionais também é perceptível no âmbito visual do poema concreto formado pela letra desta canção. O processo de desconstrução e reconstrução da letra da canção forma um desenho que pode ser interpretado como uma meia bandeira do Brasil (como se o retângulo e o losango que formam o pavilhão 
brasileiro tivessem sido seccionados pela metade) ou uma representação das asas abertas de um morcego, remetendo mais uma vez ao personagem Batman, homem-morcego.

Mesmo em envolto a inúmeras polêmicas, o disco "Tropicalia ou Panis et Circencis" foi um sucesso, catapultando assim os integrantes do grupo à atenção do público e da imprensa. Em outubro de 1968, o grupo tropicalista assumiu o comando de um programa de televisão, na TV Tupi de São Paulo, chamado "Divino Maravilhoso", nome já atribuído de forma provocativa pelo uso do termo "divino".

Figura 2: Fotografia do programa "Divino Maravilho" da TV Tupi em sua estreia em 28 de outubro de 1968. Foto Acervo "O Globo" online. Disponível em: http://acervo.oglobo.globo.com/incoming/a-traietoria-de-caetano-veloso-21616807

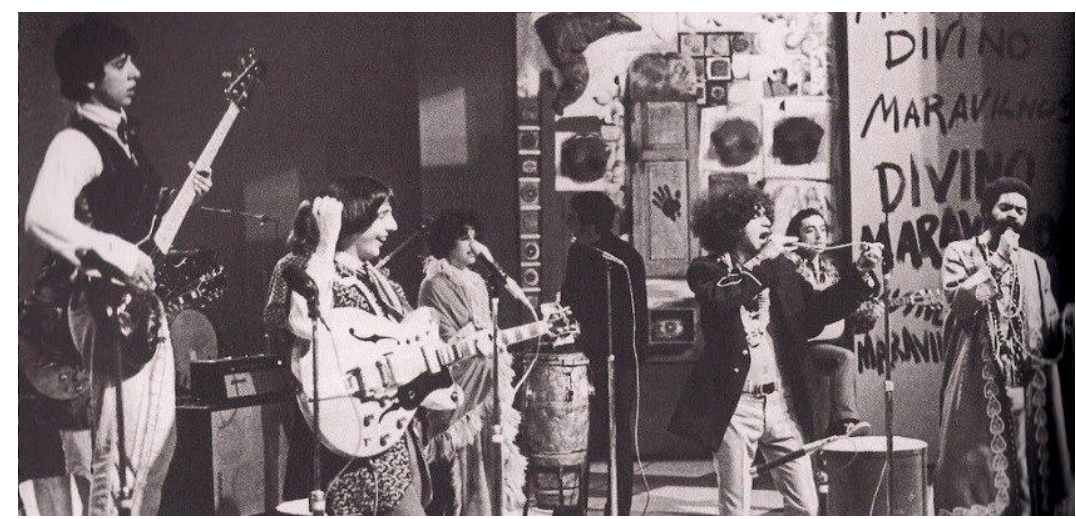

O programa serviria para consolidar não só todo o ideário musical tropicalista, mas, sobretudo, a concepção estética que regia o movimento. Gil em um dos programas representou Jesus Cristo em uma Santa Ceia, composta de frutas tropicais que no fim do programa foram jogadas ao público. Havia uma jaula também que cobria quase todo o palco e mendigos e hippies participavam de um banquete. Jorge Ben tocava violão em uma gaiola pendurada no teto. Sobre a estreia do programa e a consolidação de suas ideias, a Folha de S. Paulo destacou em 30 de outubro de 1968.

Um novo conceito estético, radicalmente desvinculado do passado ("Isso que anda por aí está tudo velho", disse Caetano) e, integralmente integrado no presente - não no futuro - é o que pretendem os baianos e foi o que procuraram mostrar anteontem na estréia de "Divino, Maravilhoso" (Folha de S. Paulo - 30 de outubro de 1968).

Folha de S. Paulo não teceu críticas ao programa dos "baianos tropicalistas", apenas vaticinou certo futuro ao movimento.

É um programa quente, movimentado, tropical, imaginativo, diante do qual ou se tem amor ou ódio e que, por isso mesmo, vai dividir muito a opinião pública. Se pegar, como tudo indica, poderá ser para a música nova, o "som livre", o mesmo que 
foi "O Fino da Bossa" para o tipo de música de que os baianos agora querem distância (Folha de S. Paulo - 30 de outubro de 1968).

A tropicália como "movimento organizado" teve curta duração, atuando até dezembro de 1968, quando foi decretado o AI-5 (13 de dezembro de 1968) e Caetano e Gil passaram a sentir mais fortemente o julgo da censura e da repressão militar-estatal. A dupla foi presa no Rio de Janeiro em 27 de dezembro de 1968, sob acusação de desrespeito à pátria. Ficaram em cárcere até fevereiro de 1969, sendo libertados sob a condição de manterem-se em confinamento domiciliar. Após shows nos dias 20 e 21 de fevereiro de 1969, Caetano e Gil partiram pra um exílio na Inglaterra que duraria até 1972. Fase que transformaria significativamente suas produções musicais. O programa de TV continuou sendo apresentado por Tom Zé, no entanto, foi retirado do ar após as prisões de Caetano e Gil.

\section{Conclusão}

A Tropicália, sem dúvida, foi um dos movimentos culturais que, mais significativamente, imprimiram uma marca indelével na história da música brasileira, assim como a Bossa Nova, a Jovem Guarda e a MPB. Não só na expressão musical, mas também nas artes plásticas e, sobretudo, na experiência comportamental. Os jovens artistas baianos (a faixa etária média era entre 25 e 26 anos) assimilaram os ideais dos movimentos de contracultura que fervilhavam pela Europa e pelos Estados Unidos e produziram um movimento próprio que propunha uma reflexão sobre a identidade brasileira, bem como reclamava uma transformação no conservadorismo social. O grupo trazia como objetivos maiores denunciar a miséria do país e de sua população, ao mesmo tempo que proclamavam a riqueza cultural do povo brasileiro. De certo modo, o movimento também se propunha a evidenciar as facetas do poder autoritário e da repressão, engendrados pela implantação de um regime ditatorial militar.

O objetivo primaz no presente artigo foi desvelar determinadas características do tropicalismo, a partir do álbum coletivo produzido em 1968. Os elementos pertinentes ao movimento ainda se manifestariam em outros álbuns individuais dos componentes do grupo. O álbum-manifesto permanece como símbolo desse movimento, de tamanha pujança na música brasileira do século XX.

O tropicalismo logrou grande êxito e alcance na música popular brasileira. Desde 1968 e até os dias atuais, as músicas naquele momento compostas geram um novo olhar e continuam sendo algo novo, fora daquilo que já foi feito. Era essa a intenção desde o início do 
movimento, trabalhar com algo diferente do que já existia, sem ser direcionada a nenhuma classe (VELOSO, 2012). O "novo" que os tropicalistas propunham era para todos, era algo para ser ampliado no mercado cultural. De forma inédita para o período (e para os anos que se seguiriam, tendo em visto o recrudescimento do aparelho repressor) o movimento não ligavase a nenhum partido, ansiava por promover a racionalidade, o fazer pensar.

Transcorridos cinquenta anos do álbum "Tropicalia ou panis et circencis", é fundamental que lembremos que, apesar do relativo êxito em 1968, o disco não se tornou canônico. Isto é, ele permanece provocativo e chocante para determinados setores da sociedade. Isso se explica, especialmente, pelo aprofundamento da ditadura militar imediatamente em 1968 - que trouxe consigo uma consolidação de certos posicionamento conservadores, especialmente nas formas de comportamento e nas relações com a religião.

É no entendimento que o trabalho historiográfico trabalha no profícuo diálogo entre presente e passado que nos propusemos a construir esse texto, partindo de uma fonte de pesquisa musico-visual. Desse modo, para finalizar, é preciso acrescentar que seja exaltando a mulher da periferia, percebendo a industrialização e o consumismo inserido na cultura, resgatando elementos das religiosidades afro-brasileiras ou veementemente criticando os comportamentos burgueses das famílias brasileiras, "Tropicália ou panis et circencis" permanece provocativo e polêmico, uma vez que determinadas críticas e observações apontadas pelos tropicalistas há meio século conservam-se pertinentes e contundentes no Brasil contemporâneo. Talvez não a questão e estética musical, mas as normas e padrões comportamentais, essencialmente extraídas de uma vivência burguesa. O vaticínio de Caetano, em Baby, permanece atual "você precisa saber".

\section{Notas}

\footnotetext{
${ }^{1}$ Um golpe civil-militar impetrado em 31 de março de 1964 depôs o Presidente da República, João Goulart e implantou um regime militar. O regime foi intensificado a partir de 1968, e permaneceria vigente até 1985 , quando da posse do primeiro presidente civil - eleito em pleito indireto - em duas décadas.

${ }^{2}$ Esse fenômeno também é analisado por Hobsbawm (2012).

3 A canção "Tô" compõem o álbum "Estudando o samba" de 1976, lançado pela gravadora Continental. O álbum foi escolhido pela revista Rolling Stones, em 2007, como $35^{\circ}$ melhor álbum brasileiro de todos os tempos.

${ }^{4}$ José Abelardo Barbosa de Medeiros, conhecido como Chacrinha, foi um radialista e apresentador de televisão brasileiro. Seus programas televisivos, especialmente os Buzina do Chacrinha e Discoteca do Chacrinha, exibidos na Rede Globo, eram de enorme sucesso popular, lançando para a consagração de público diversos artistas.

${ }^{5}$ Caetano Veloso (1997, p. 278-279) reconhece que houve um erro de grafia (não proposital) no uso do latim para o título do álbum. Na expressão que deveria ser escrita "Panis et circenses", com o "e" ao invés do "i", e "s" ao invés de "c".
} 


\footnotetext{
${ }^{6}$ Geshman foi o responsável pelo layout e pelos grafismos na arte da capa do álbum-manifesto.

7 "Carolina" uma canção de Chico Buarque de Holanda classificada em terceiro lugar no II Festival Internacional da Canção Popular, realizado pela TV GLOBO em outubro de 1967. A faixa também integra o disco "Chico Buarque de Holanda volume 3" de 1968.

${ }^{8}$ É um personagem das histórias em quadrinho criado por Bill Finger e Bob Kane em 1939. O personagem logrou imenso sucesso que nos anos 1960 ganhou um seriado televisivo, enraizando na cultura pop.

9 A matéria era intitulada "Baianos na TV"
}

\section{Referências Bibliográficas}

BARROS, P. M. Provocações Brasileiras: a imprensa contracultural made in Brazil: Coluna Underground (1969-1971), Flor do Mal (1971) \& a Rolling Stone Brasileira (1972-1973). Assis, 2007. 200f. Tese de Doutorado em História - Universidade Estadual Paulista, 2007

BASUALDO, Carlos. Tropicália - uma revolução na cultura brasileira. $1^{\text {a }}$ edição. São Paulo: Cosac-Naofy: 2007, 379p.

COHN-BENDIT, Dany. Nós que amávamos tanto a revolução: 20 anos depois. $1^{\mathrm{a}}$ edição. São Paulo: Brasiliense, 1987, 189p.

CORREIA, Tupã. Nos passos da moda: mídia, consumo X mercado cultural. Campinas, Papirus, 1989

FAVARETTO, Celso. Tropicália alegoria alegria. 3 edição. Cotia: Ateliê Editorial, 2000.

FICO, Carlos. História do Brasil Contemporâneo. $1^{a}$ edição. São Paulo: Contexto, 2015, 160p.

GARCIA, Miliandre. Entre o palco e a canção: afinidades eletivas entre a Música Popular Brasileira (MPB) e o Teatro Engajado na década de 1960. Modos. v. 1, n. 3 (2017) https://doi.org/10.24978/mod.v1i3.892, v. 1, p. 264-283, 2017.

HOBSBAWM, Eric J. Os revolucionários. $2^{\mathrm{a}}$ edição. Rio de Janeiro: Paz e Terra, 1985, 280p. . Era dos extremos: o breve século XX: 1914 - 1991. 2a edição. 48 ${ }^{a}$ reimpressão. Tradução: Marcos Santarrita. São Paulo: Companhia das Letras, 2012, 598p.

MATTE, Ana Cristina Fricke. Bat Macumba Oba! A anti-letra da canção. Estudos Lingüísticos (São Paulo), Campinas, v. XXXIV, 2005.

PEREIRA, Carlos A. M. O que é contracultura. $2^{a}$ edição. São Paulo: Brasiliense, 1984, 97p.

ROSZAK, Theodore. A contracultura. $2^{a}$ edição. Petrópolis: Vozes, 1972, 301p.

VELOSO, Caetano. Verdade Tropical. São Paulo. Companhia de Bolso, 2012, 520p.

VENTURA, Zuenir. 1968: O ano que não terminou. São Paulo, Planeta do Brasil, 2008, $314 \mathrm{p}$.

\section{Periódicos:}

Folha de S. Paulo - 30 de outubro de 1968

\section{Filmografia:}

Terra em Transe. Direção de Glauber Rocha. Rio de Janeiro: Mapa Filmes e Difilm, 1967 (107 min).

Tropicália. Direção de Marcelo Machado. São Paulo: BossaNovaFilms e Record Entretenimento, 2012 (82 $\mathrm{min})$

Uma noite em 67. Direção de Ricardo Calil e Renato Terra. Rio de Janeiro, VideoFilmes. 2010. (93 $\mathrm{min})$

\section{Discografia :}

Tropicália ou Panis et Circencis. São Paulo: RGE, 1968 (1 disco) 